\title{
JELLEMZÓ MEGKÜZDÉSI MÓDOK ÉS A TÁRSADALMI PROBLÉMÁK KEZELÉSE
}

\author{
NAGY LUCA-BALÁZS KATALIN \\ Debreceni Egyetem, Pszichológiai Intézet \\ E-mail: nagyluca0406@gmail.com
}

Benyújtva: 2019. szeptember 6. - Elfogadva: 2020. augusztus 25.

Háttér és célkitúzés: A vizsgálat célja a társadalmi problémák megoldására vonatkozó viselkedéses szándékok felmérése, a vizsgálati személyek megküzdési stílusának és szociálisprobléma-megoldó képességeinek függvényében. A vizsgálat elméleti alapjául az attitüdök és a viselkedéses szándékok kapcsolatát tárgyaló Tervezett Viselkedés Elmélete (TVE, Ajzen, 1991), valamint a megküzdés és a szociálisprobléma-megoldás irodalma szolgál; korábbi kutatási eredményeink a vizsgálat empirikus elözményeinek tekinthetôk (pl. Nagy és Balázs, 2018a).

Módszer: A vizsgálat kérdôives módon zajlott, a személyek online felületen vagy papíralapon jelölték meg válaszaikat, célcsoportunk a felnött korosztály volt. A vizsgálati személyek a szociálisprobléma-megoldás felmérésére alkalmas SPSI-R (Social Problem-Solving Inventory-Revised, D'Zurilla, Nezu és Maydeu-Olivares, 2002, adaptálta Kasik, Nagy és Füzy, 2009) skála, illetve a megküzdési stílusokat felmérố CISS-48 (Coping Inventory for Stressful Situations, Endler és Parker, 1994) kérdéseit válaszolták meg. Továbbá, a klimaváltozás, a természetes élóhelyek védelme, a diabétesz, az egészséges életmód, a nélkülözó gyermekek megsegitése és a családon belüli erôszak megelôzése kapcsán a problémák kezelésére irányuló viselkedéses szándékukról nyilatkoztak. A mintát 275 fö, 109 férfi és 166 nô alkotja; átlagéletkoruk 30 év, többségében gimnáziumi és felsöfokú végzettséggel rendelkeznek.

Eredmények: A vizsgálat eredményei alapján a különbözố társadalmi problémák kezelésére vonatkozó viselkedéses szándékaik alapján a személyek három csoportja képezhetố, mely csoportok életkoruk, megküzdési stílusaik és szociálisprobléma-megoldási képességeik tekintetében egyértelmüen elkülönülnek.

Következtetések: Habár a társadalmi problémák megoldására vonatkozó viselkedéses szándékok alakulását egyéb tényezók is befolyásolhatják, eredményeink alapján mindenképpen hatással van rájuk az életkor, a jellemzố megküzdési stílus, valamint a szociálisprobléma-megoldás képessége.

Kulcsszavak: attitüd, viselkedéses szándék, társadalmi célok, megküzdés, szociálisprobléma-megoldó képesség 


\section{BEVEZETÉS}

A tanulmányban bemutatott vizsgálat célja, hogy a társadalmi problémák megoldására irányuló viselkedéses szándékokat az egyénre jellemzô megküzdési és szociálisprobléma-megoldó stílusokkal összefüggésben vizsgálja.

A tanulmányban közölt vizsgálat újszerúségét az adja, hogy a társadalmi nehézségek kezelésének szándékában megmutatkozó különbségeket a szociálisprobléma-megoldás képességével hozza összefüggésbe; az utóbb említett konstruktum a vonásszintú megküzdés függvényében kerül vizsgálatra. Mindez a célcsoport szegmentációját és alcsoportok jellemzôinek elemzését és az ebbôl fakadó mélyebb megértését szolgálja. A kutatási eredmények gyakorlati haszna, hogy felhasználásukkal, konkrétabban a társadalmi célú kommunikáció stratégikus alakításával, azok hatékonyságát növelheti.

Korábbi vizsgálataink során (Nagy és Balázs, 2018a; Nagy és Balázs, 2018b; Nagy és Balázs, megjelenés alatt) kettô, illetve négy eltérô problémát megjelenítố társadalmi célú reklámot ítéltek meg a vizsgálati személyek. A reklámüzenetek témái különböztek aszerint, hogy kinek az érdekét szolgálják: az egyénét, valaki másét vagy egy másik csoportét, vagy a társadalom egészéét (Sas, 2010). Ennélfogva különböztek abban, hogy milyen mértékú kontrollal bír az egyén a probléma megoldására nézve. A reklámokra adott reakcióikat a személyek diszpozicionális megküzdési stílusával, valamint kontrollhelyével vetettük össze, figyelembe véve a reklámok témáját és a félelemkeltés mértékét. A változók összetett modelljében a megküzdés, a kontrollhely és a témák interakciós hatása mutatkozott meg a reklámok megítélésére vonatkozóan (Nagy és Balázs, megjelenés alatt).

Célkitúzésünk a jelen tanulmányban bemutatott vizsgálat esetén, hogy egymás mellett tanulmányozhassuk a kontrollálhatóságuk szerint eddig különállóan kezelt társadalmi problémákat. További célunk, hogy részleteiben vizsgáljuk a szociális problémák megítélését, ami a társadalmi célok kommunikációjának alapja. Vizsgálatunk fókuszában - a korábbi empirikus eredmények alapján - az egyének hozzáállásának tanulmányozása áll, a megküzdés és a szociálisprobléma-megoldás függvényében. A szociálisprobléma-megoldás beemelésének apropóját részben a megküzdés és a szociálisprobléma-megoldás közötti összefüggések adják (pl. Zsolnai és Kasik, 2016).

Az attitûdök és a viselkedéses szándékok kapcsolatát tárgyaló Tervezett Viselkedés Elmélete (Ajzen, 1991) a kutatás fontos megalapozója. A modell a viselkedésváltozás ösztönzése szempontjából is alapvetô; a meggyôzés folyamatának értelmezési keretét adja. A személyek diszpozicionális megküzdése (pl. Endler és Parker, 1990b), valamint szociálisprobléma-megoldása (pl. D’Zurilla és Nezu, 1982) előrevetítheti, hogy a potenciális stresszt okozó társadalmi kérdések esetén mennyiben áll a személyek szándékában e problémák kezelése. A társadalmi problémák kapcsán lényeges említést tenni arról, hogy ki(k)nek az érdekét szolgálja azok megoldása, kezelése.

A vizsgálatban a személyek társadalmi problémákra vonatkozó viselkedéses szándékait mértük fel. A témák konkrétan a klímaváltozás, a természetesélôhely-védelem, a diabétesz-szúrôvizsgálat, az egészséges életmód, a nélkülözó gyermekek megsegítése, valamint a családon belüli erôszak voltak. Mindezt a személyek diszpozicionális megküzdése, azaz a feladat-, érzelem- és elkerülésorientált stílusok jellemzô volta (Endler 
és Parker, 1994); továbbá a szociálisprobléma-megoldás (Kasik, Nagy és Fưzy, 2009) öt dimenziójának, azaz a pozitív és negatív orientáció, illetve a racionalitás, impulzivitás és elkerülés megoldási módjainak jellemzô alkalmazása függvényében vizsgáltuk.

\section{AZ ATTITÛD, A MEGGYŌZÉS ÉS A VISELKEDÉSES SZÁNDÉK KAPCSOLATA}

Az attitûdök kialakulása során különbözô tárgyak, az ún. attitûdtárgyak (Eagly és Chaiken, 1995) kedveltségének felbecslése zajlik (Eagly és Chaiken, 1993). Az attitúdtárgyakkal való találkozás kiértékelési folyamatának eredményei az attitûdök (Eagly és Chaiken, 1995), melyek viselkedéses, érzelmi és kognitív tapasztalatokon nyugszanak; valamint egyaránt kihatással vannak az egyén viselkedésére, érzelmeire és kognícióira (Petty és Cacioppo, 1986).

A meggyôzés folyamatát az attitûd konstruktuma alapozza meg: a meggyôzés során attitúdök formálódhatnak, a már korábban kialakultak megerôsödhetnek, vagy új attitúdök jöhetnek létre (Miller, 1980; Síklaki, 1994). Az alkalmazott szociálpszichológia egyes területei és a fogyasztói magatartás pszichológiája is célozza annak megértését, hogy mely kampányok, kommunikációs stratégiák és beavatkozások végzôdnek az elvárt eredményekben; ami leggyakrabban a viselkedés megváltozását jelenti (Haugtvedt és Kasmer, 2008).

Az attitûdök, a viselkedéses szándékok és a viselkedés közötti összefüggések szempontjából fontos kitérni a Tervezett Viselkedés Elméletére (Ajzen, 1991). A modell alapelképzelése, hogy a viselkedés mellett való elkötelezôdés során, az emberek racionálisan kalkulálnak a költségekkel és nyereségekkel; és számolnak azzal, hogy a viszonyítási alapul szolgáló „fontos mások” hogyan vélekednek az adott cselekvésrôl. Az elmélet fố elemei, melyeket az 1. ábra is bemutat, a viselkedésre vonatkozó attitûdök, a szubjektív normák (Perloff, 2003), az észlelt viselkedéses kontroll (Ajzen, 1991), a viselkedéses szándék, valamint a viselkedés maga (Perloff, 2003).

Ajzen és Fishbein (2005) szerint az attitüd részben a viselkedéssel kapcsolatos hiedelmeket, részben annak következményeire vonatkozó becsléseket foglalja magában. A szubjektív normák a normatív hiedelmekbôl, az ezeknek megfelelő viselkedésre irányuló motivációból épülnek fel (Perloff, 2003): amikor az egyén úgy értékeli, hogy a fontos személyek elvárják tôle az adott viselkedést, az társas normaként hat rá, így várhatóan elkötelezôdik a viselkedés iránt (Ajzen és Fishbein, 2005). Az Ajzen (1991) által bevont észlelt viselkedéses kontroll tényezôje olyan aktuális kontrollt jelez, amely nem

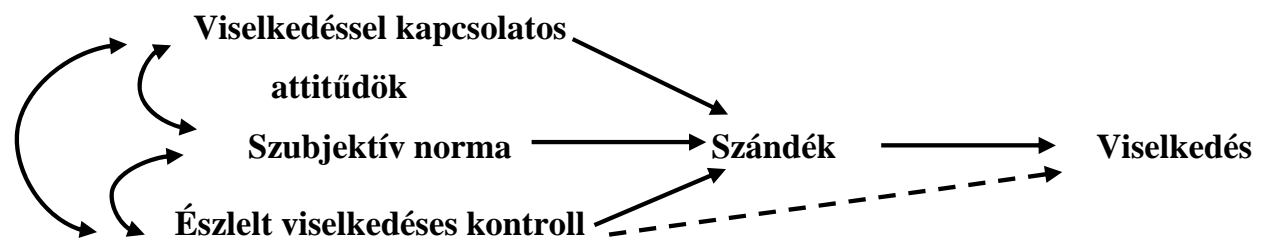

1. ábra. A Tervezett Viselkedés Elmélete (Ajzen, 1991, 182. alapján) 
motivációs eredetú összetevơket is tartalmaz, mint a pénz, idô vagy képességek; melyek szintén kiemelt fontosságúak lehetnek a viselkedés végrehajtásában. E komponenshez tartozik az egyén szituáció és viselkedés felett észlelt szubjektív kontrollja, melynek függvényében adott körülmények között könnyúnek, vagy nehéznek értékeli a viselkedés végrehajtását. A viselkedéses szándék arra vonatkozik, hogy a személy milyen nehézségek árán és erôfeszítések révén hajlandó kivitelezni a cselekvést. A modellben a viselkedéses szándékra az attitûdök, a szubjektív normák és az észlelt viselkedéses kontroll tényezôi hatnak (Perloff, 2003). A viselkedéses kontroll és a viselkedéses szándék együttesen, akár direkt módon is elôrejelezhetik a viselkedést, amennyiben a mérés pontos, és az észlelt kontroll képes helyettesíteni az aktuális kontrollt (Ajzen, 1991), mint ahogyan azt az 1. ábra is jelöli.

Adott viselkedést célzó meggyôzés esetében fontos számolni azzal a szemponttal, hogy kinek/kiknek az érdekében áll a viselkedés megváltoztatása. Sas (2010) szerint a társadalmi célok nem képeznek homogén egységet, alapvetôen különböznek az érdek tekintetében; azaz abban, hogy az egyén, mások vagy a teljes közösség érdeke füzôdik a szóban forgó társadalmi probléma megoldásához.

Az egyén jóllétét szolgáló üzenetek esetében a viselkedés megváltoztatása közvetlenül a számára is hasznot hoz, idesorolhatók az életmóddal, egészséggel kapcsolatos kérdések (Sas, 2010). Ezek mind olyan célok, amelyek felett direkt kontrollja van a személynek.

A mások, általában egy hátrányos helyzetben lévô társadalmi csoport megsegítését kérô üzenetek hirdetôii a szívességért cserébe semmit sem tudnak felkínálni, így az üzenet befogadójának jutalma az adakozás, segítségnyújtás, karitatív cselekedet révén erkölcsi, etikai, vallási természetú. Ez esetben az üzenet hatékonysága nagyban függ attól, hogy sikerül-e érintettséget kelteni a befogadóban (Sas, 2010). A direkt érintettség hiánya miatt kevésbé involvált a befogadó; ugyanakkor úgy észlelheti, hogy nincs kontrollja a nehézségek felett, így a hozzájárulása elmaradhat.

A közös érdekeket szolgáló üzenetek témái a nagyobb közösség tagjaként élố befogadót közvetlenül, viszont hosszú távon érintik; a problémák megoldásához az egyén részvétele, hozzájárulása szükséges. Ilyen társadalmi célok többek között a környezetvédelem, a globális felmelegedés akadályozása és az állatvédelem. Az egyén részesülése a kívánt viselkedés pozitív hozadékaiból közvetett, mivel maguk a problémák és hatásaik időben és térben távoliak (Sas, 2010). Az egyén kontrollja a közös érdekú nehézségek megoldásában közvetett, ám mégis valamivel fokozottabb, mint a mások érdekét szolgáló üzenetek esetében.

\section{A MEGKÜZDÉS}

A megküzdés meggyőzô üzenetek megítélése kapcsán történô tanulmányozását empirikus kutatások (pl. Rippetoe és Rogers, 1987; So, Kuang és Cho, 2016), valamint korábbi vizsgálataink (pl. Nagy és Balázs, 2018a) alapozzák meg. Az előbb említett munkák elsôsorban az egészségviselkedésre vonatkozó meggyôző üzenetekre fókuszáltak, míg saját kutatásainkat további társadalmi problémákra, mint például a kör- 
nyezet- és állatvédelem, vagy a nôk elleni erôszak témáit megjelenítô társadalmi célú reklámüzenetekre is kiterjesztettük. A vizsgálati eredmények alapján komplex összefüggés tárható fel a meggyôzô üzenetek megítélése és a diszpozicionális megküzdés között, mely kapcsolat lényeges meghatározója lehet a társadalmi célú reklámüzenet által megjelenített téma (Nagy és Balázs, 2018a). Tapasztalataink szerint fontos befolyásoló tényezô, hogy a társadalmi probléma mennyire énközeli, milyen mértékben múlik az egyén kontrollján annak megoldása (Nagy és Balázs, 2018b). Jelen munkában a különbözó társadalmi problémák megoldását célzó viselkedéses szándékokat a diszpozicionális megküzdéssel összefüggésben vizsgáljuk. A megjelenített társadalmi problémák pedig témájukat tekintve mindhárom érdektípust lefedik (egyén, mások, nagyobb közösség).

A megküzdés vagy coping fogalma kognitív és viselkedéses erôfeszítéseket, cselekvéseket foglal magában, amelyek segítségével az egyén képes kezelni, csökkenteni és megszüntetni az erôforrásait igénybe vevô, külsố és/vagy belsố konfliktusokat (Folkman és Lazarus, 1980). A megküzdési reakciók olyan esetekben jelennek meg, amikor az egyén stabil múködését megrendítô, általános értelemben véve megterhelô eseménnyel találkozik. A megküzdés újabb nézôpontok szerint olyan gondolatok, viselkedések és érzelmek összességét jelenti, amelyek szándékosak, tudatosak, és erôfeszítést igényelnek (Tiringer, 2014), összevetve az elhárító mechanizmusokkal.

Többféle megküzdési stílus, megküzdési mód került azonosításra a szakirodalomban. A szakemberek nagy része egyetért abban, hogy a Folkman és Lazarus (1980) által elkülönített probléma- és emóciófókuszú megküzdési módok alapvetônek tekinthetôk (Parker és Endler, 1992). A problémafókuszú megküzdés kognitív, a probléma megoldására vonatkozó erôfeszítéseket, viselkedéses stratégiák kialakítását foglalja magában, amikor a cél a stresszforrás átalakítása. Az érzelemfókuszú megküzdési mód alkalmazása ugyanakkor a stresszor kiváltotta érzelmi distressz csökkentését, kezelését szolgálja (Folkman és Lazarus, 1980).

A megküzdés értelmezésével kapcsolatos elképzelések és mérésére kialakított eszközök különbözôségének egyik fô szempontja, hogy hogyan tekintenek a megküzdésre: dinamikusan változóként, ami az aktuális gondolatok és cselekvések által meghatározott (Lazarus és Folkman, 1984); vagy szokáson alapulóként aszerint, hogy általában a személy hogyan kezeli a nehézséget okozó helyzeteket (Carver és Scheier, 1994). Elôbbi a megküzdés szituatív nézôpontja, utóbbi pedig személyiségvonásként tekint a konstruktumra (Tiringer, 2014). A vonásszintú nézôpont képviselôi gyakran úgy hivatkoznak a megküzdésre, mint megküzdési viselkedés vagy megküzdési stílus (pl. Endler és Parker, 1990b, 1990c).

A tanulmányban bemutatott vizsgálatban a vonásalapú megközelítést alkalmazzuk a korábbi vizsgálatainkkal megegyezôen, ezért a továbbiakban Endler és Parker (1990b, 1990c) megközelítését részletezzük. A szerzôk a megküzdés egy valid és megbízható skálájának kialakítását célozták, mert a Lazarus és Folkman rendszerén alapuló eszköz pszichometriai jellemzőit problémásnak vélték. A fogalmakat tekintve a probléma- és érzelemfókuszú megküzdési módok meghatározásától valamelyest eltértek (Endler és Parker, 1990b): a problémafókuszú megküzdésre feladatorientált, míg az emóciófókuszúra érzelemorientált megküzdési stílusokként utalnak. Feladatorientált megküzdés- 
ként olyan viselkedéseket tartanak számon, amelyek a probléma megoldására, újraértelmezésére, a stresszor hatásának csökkentésére adnak lehetôséget. Az érzelemorientált megküzdés alatt érzelmi válaszok kialakítását, más cselekvési módok elképzelését, illetve az egyén saját magával kapcsolatos érzelmeire, gondolataira való fókuszálását értik (Parker és Endler, 1992). Megállapítottak egy harmadik, elkerülésorientáltként elnevezett stílust, amely feladat- és személyre orientált jegyeket is tartalmazhat. Elôbbit példázza, amikor egy másik cselekvésbe fog az egyén a stresszokozó helyett; utóbbit pedig, amikor társas támogatást keres (Endler és Parker, 1990b).

A megküzdés jelenségével foglalkozó szakirodalmak sok esetben a coping adaptív vagy maladaptív jellegét hangsúlyozzák, ennek kapcsán pedig az „illeszkedés jóságáról” szóló hipotézist (goodness of fit hypothesis, pl. Conway és Terry, 1992) vizsgálják. A feltételezés szerint a problémafókuszú megküzdés akkor tekinthetô adaptívnak, amikor a helyzetet kontrollálhatónak véli a személy; és akkor maladaptívnak, ha kontrollálhatatlanként értékeli azt. Ezzel szemben az érzelemfókuszú megküzdés adaptívnak gondolható a kontrollálhatatlan helyzetekben; míg maladaptívnak, ha a szituáció kontrollálhatónak tûnik (Conway és Terry, 1992; Endler, Speer, Johnson és Flett, 2000).

A végeredmény feletti kontroll és a megküzdés adaptív jellegére vonatkozó vizsgálatok azonban vegyes eredményekkel szolgáltak. Conway és Terry (1992) szituatív megküzdési módokat vizsgáló kutatásának eredményei nem erôsítették meg a hipotézist, miszerint a kontrollálhatatlan helyzetekben maladaptív lenne a problémafókuszú megküzdés, vagy hogy ezekben a helyzetekben az érzelemfókuszú stratégiák előnyösek. Nem nyert megerôsítést az a feltevés sem, hogy a problémafókuszú stratégiák alkalmazása az esemény kontrollálhatóságától függ. Endler, Summerfeldt és Kantor (1993, idézi Endler és mtsai, 2000, 246) kutatása jelen tanulmány szempontjából kiemelkedôen fontos, ugyanis a diszpozicionális megküzdés vizsgálatára is kiterjedt. Az illeszkedésrôl szóló hipotézist szintén cáfolva, a vizsgálat fô eredményei szerint az észlelt kontroll csak kismértékben jósolja be az alkalmazott megküzdési stratégiákat és a distresszt; rájuk nézve nagyobb prediktív ereje mutatkozott meg a vonásszintú feladat-, érzelem- és elkerülésorientált megküzdési stílusoknak.

Endler és munkatársai (2000) különbséget tettek objektív és észlelt kontroll között, és ezek vonatkozásában tanulmányozták a megküzdést. Az objektív kontroll alatt az aktuálisan az adott helyzetre vonatkozó kontroll mértékét értették, hogy van-e olyan hozzáférhetố válasz(reakció) a helyzetben, amelyet a személy akkor tud alkalmazni, ha találkozik a stresszt okozó eseménnyel. Míg az észlelt kontroll a személy a szituáció kimenetének kontrollálhatóságára vonatkozó szubjektív észleletét jelentette. Eredményeik alapján az észlelt kontroll erôsebb összefüggést mutatott a megküzdési módokkal: a magasabb észlelt kontroll kevesebb szituatív érzelmi megküzdést és fokozottabb feladatorientált megküzdést eredményezett, mint az alacsonyabb észlelt kontroll. Alacsonyabb észlelt kontroll mellett gyakrabban alkalmazásra került az érzelemorientált megküzdés, ám használata nem függött az objektív kontroll mértékétôl. Ezek az eredmények rávilágítottak a kontroll jellegének fontosságára.

Összességében tehát valószínúsíthetô, hogy a feladatorientált megküzdés alkalmazását az észlelt kontroll mértéke befolyásolja leginkább. 


\section{A SZOCIÁLISPROBLÉMA-MEGOLDÁS}

A szociálisprobléma-megoldás a problémamegoldás azon folyamatát jelenti, amely a természetes környezetben, a „való világban” jelenik meg (D’Zurilla és Nezu, 1982, idézi D’Zurilla, Nezu és Maydeu-Olivares, 2004, 11). A „társas” megnevezés nem arra utal, hogy a szociálisprobléma-megoldás bármilyen kifejezett problématípus vizsgálatára korlátozódik, hanem szerepe annak kiemelése, hogy az érdeklôdés olyan problémamegoldás körére vonatkozik, amely a való élet társas közegében történô adaptív létet, múködést befolyásolja.

A szociálisprobléma-megoldás vizsgálata minden olyan problématípusra kiterjed, amely az egyén múködését érintheti, úgymint: személytelen problémák (pl. elégtelen anyagi helyzet); személyes vagy személyen belüli problémák (pl. érzelmi, viselkedéses, egészségügyi nehézségek); interperszonális problémák (pl. családi viták, házassági konfliktusok). Továbbá idesorolhatók a szélesebb értelemben vett közösségi, társadalmi problémák, mint a búnözés vagy faji diszkrimináció (D’Zurilla és mtsai, 2004, 11).

A szociálisprobléma-megoldás az egyén által irányított kognitív-viselkedéses folyamatot jelent, amelyben a mindennapok során felmerülô problémás helyzetek hatékony megoldási módjainak azonosítására, feltárására kerül sor. A szociálisprobléma-megoldás tudatos, racionális, erôfeszítést igénylő, szándékolt megküzdési folyamat, amely hozzásegíti az egyént ahhoz, hogy hatékonyan kezelje a stresszt okozó helyzetek széles körét (D’Zurilla és Nezu, 1982, idézi D’Zurilla és Chang, 1995, 548).

A szociálisprobléma-megoldó képesség két általános, részben független komponensbôl áll. Ezek a problémaorientáció és a problémamegoldó képesség (D’Zurilla és mtsai, 2002, idézi D’Zurilla és mtsai, 2004, 17). A problémaorientáció viszonylag stabil kognitív-érzelmi sémák múködése arra vonatkozóan, hogy a személy általában hogyan gondolkodik és érez a problémákkal és saját problémamegoldó képességeivel kapcsolatban. A problémamegoldó képesség a megoldási mód racionális kiválasztása, mely során az egyén problémamegoldó készségeket és technikákat alkalmaz, hogy megtalálhassa a legjobb megoldást jelentô alternatívát az adott probléma esetén (D'Zurilla és Chang, 1995; Maydeu-Olivares és D’Zurilla, 1996).

Maydeu-Olivares és D’Zurilla (1996) megerôsítették egy ötfaktoros modell illeszkedését, melyben a két fố komponens további tényezôkre bomlik: pozitív és negatív problémaorientációra; racionális, impulzív/nemtörôdöm, valamint elkerülô problémamegoldási stílusokra.

A pozitív problémaorientáció konstruktív problémamegoldási módokat magában foglalva egyfajta általános hajlamot ragad meg, amely révén a probléma úgy értékelendô, mint kihívás. A pozitív problémaorientáció fokozott mértéke mellett az egyén hiszi, hogy a problémák általában megoldhatók; hogy képes sikeresen megoldani a problémákat; hogy a problémák megoldása idô- és energiabefektetést igényel; illetve rendelkezik azzal a magabiztossággal, hogy a problémák megközelítésével lehet sikeres a megoldásuk. A negatív problémaorientáció ezzel szemben egy diszfunkcionális vagy gátló motivációs tényezôket tartalmazó gyújtemény. Ennek révén a személy úgy tekint a problémára, mint amely fenyegetést jelent a jóllétére; kételkedve abban, hogy a képességeivel sikeresen megoldható a probléma, ezért könnyen frusztrálttá, idegessé válhat, amikor szembesül azzal. 
A racionális problémamegoldás konstruktív megoldási forma, a megoldási képességek racionális, átgondolt, szisztematikus használatát foglalja magában. Az impulzivitás esetében diszfunkcionális mintázat van jelen, az egyén igyekszik követni a megoldási stratégiákat, azonban ezek a próbálkozások beszúkültek, figyelmetlenek, elsietettek és nem kidolgozottak. Az elkerülő megoldási stílust szintén diszfunkcionálisnak tekintik, a halogatás, passzivitás vagy inaktivitás és a függôség „megoldási módjai” jellemzik. Az elkerülô problémamegoldók a konfrontálódást kerülik, késleltetik a konfliktus kezelését, nemritkán másra hárítják a felelősséget (D’Zurilla és mtsai, 2004, 15-17).

A társadalmi problémák megoldására vonatkozó folyamatok így egy szeletét képezik azon problémamegoldást igénylố helyzeteknek, amelyek esetében a szociálisprobléma-megoldó képességek relevánsak. Vizsgálatunkban olyan társadalmi problémák megoldásával kapcsolatos szándékokra vonatkozóan tanulmányozzuk ezeket a képességeket, mint a klímaváltozás, az élóhelyek védelme, a cukorbetegség megelőzése, az egészséges életmód megórzése, a nélkülözô gyermekek megsegítése és a nôk elleni erôszak ellen való fellépés. A felsorolt társadalmi nehézségek a szociálisprobléma-megoldás függvényében történố tanulmányozását más kutatási elôzmények nem alapozzák meg; azonban az elméleti kapcsolat lehetôségét a definíció elôrevetíti.

A szociálisprobléma-megoldás és a megküzdés konstruktumainak összefüggéseit ellenben több tanulmány is tárgyalja. D’Zurilla és Nezu (2007, idézi Kasik, 2015, 69-72) a problémamegoldó stílusok és a szituatív megküzdés kapcsolatát vizsgálva megállapították, hogy nem tekinthetô minden probléma stresszt okozónak, így nem minden megküzdés jelent problémamegoldást; a megoldási stílusok sem azonosak a megküzdési stratégiákkal. Ugyanakkor úgy vélik, hogy Lazarus modellje a stresszrôl és megküzdésrôl, illetve a szociálisprobléma-megoldás komplex kognitív-viselkedéses modellje integrálható abban az esetben, ha a problémás helyzet egyben stresszornak minôsíthetô (D’Zurilla és Nezu, 2007, idézi Kasik, 2015, 70).

Részben a konstruktumok közötti kapcsolat adja az apropóját annak, hogy a szociálisprobléma-megoldás bevonására is kiterjedt vizsgálatunk; illetve úgy véltük, a különbözô társadalmi nehézségeket, problémákat érdemes lehet önmagában a szociálisprobléma-megoldás szempontjából megközelíteni.

\section{EMPIRIKUS VIZSGÁLAT}

Az empirikus vizsgálat középpontjában a társadalmi nehézségek megoldására vonatkozó viselkedéses szándékok felmérése állt a megküzdési stílus, valamint a szociálisprobléma-megoldás konstruktumainak függvényében. A szakirodalmi háttér, valamint korábbi empirikus vizsgálatok eredményei ismeretében a vizsgálatot két feltételezésre alapoztuk.

\section{Hipotézisek}

Megelôzô empirikus kutatások (pl. So és mtsai, 2016), valamint korábbi vizsgálataink eredménye (Nagy és Balázs, 2018a) szerint a megküzdési stílus és a problémák megoldását jelentố viselkedéses javaslatok elfogadása összefügg. Rippetoe és Rogers (1987) 
szerint a probléma valódi megoldására irányuló megküzdési módok azok kezelését ösztönzik. A „goodness of fit” feltételezést ugyan nem erôsítették meg maradéktalanul az empirikus vizsgálatok, ám több esetben alátámasztást nyert, hogy a kontrollálható kimenetek esetén a problémára összpontosító megküzdés az adaptívnak gondolt (pl. Endler és mtsai, 2000). Ez a különbözó társadalmi célok esetében azonosítható érdekek és a helyzet kontrollálhatóságának figyelembevételét ösztönzi.

A különbözô társadalmi nehézségek megoldásának szándéka kapcsolatban áll a megküzdési stílussal olyan módon, hogy a megoldás szándéka a racionalitáson alapuló, feladatorientált megküzdéssel függ össze (H1).

A szociálisprobléma-megoldás olyan nehézségek kezelésére vonatkozik, melyek a mindennapi életben jelennek meg, beleértve a társadalmi problémákat is (pl. D'Zurilla és mtsai, 2004). A szociálisprobléma-megoldás komplex kognitív-viselkedéses megközelítése és a megküzdés modellje összekapcsolható abban az esetben, ha a problémás szituáció stresszokozó (D’Zurilla és Nezu, 2007, idézi Kasik, 2015, 70).

A szociálisprobléma-megoldás és a megküzdés konstruktumai között azonosított kapcsolat mentén feltételezzük, hogy a szociálisprobléma-megoldás képessége öszszefüggést mutat a társadalmi nehézségek kezelésére vonatkozó viselkedéses szándékokkal, olyan módon, hogy a kedvezó szándékok és a pozitív problémaorientáció és a probléma megoldására irányuló problémamegoldó képesség pozitív együtt járást mutat (H2).

\section{MÓDSZER}

A társadalmi problémák megoldására vonatkozó viselkedéses szándékok vizsgálata kérdőíves adatfelvétel keretében valósult meg.

\section{Eljárás}

A vizsgálati személyek online a Google Forms felületén, valamint papíralapon jelölhették meg válaszaikat. Az online kérdőíveket közösségi oldalak hírfolyamain és csoportjaiban osztottuk meg, illetve a személyes megkeresés útján történô toborzás lehetôségével is éltünk. A vizsgálat célcsoportja a felnôtt korosztály volt.

A kérdôívek tartalmazták a szociálisprobléma-megoldás és a megküzdési stílus skáláit, a társadalmi célú problémák megoldására vonatkozó szándékok állítássorát, valamint demográfiai adatokat felmérô tételeket. Felmértük a félelemkeltô meggyôzés további tényezôit is (pl. észlelt válaszhatékonyság, észlelt fogékonyság), azonban részletezésüktôl eltekintünk, mert a tanulmány keretében nem került sor vizsgálatukra.

Két kérdôívváltozatot alakítottunk ki a módszertani szempontokra való tekintettel. A kérdôívek tartalmilag azonosak voltak, formailag a meggyôzés tényezôiit felmérố tételsorok egymásutániságában tértek el, hogy a sorrend torzító hatását kiküszöböljük (egyenes és fordított sorrendet használtunk). Egy kérdőív kitöltése nagyjából 15-20 percet igényelt. 
A résztvevôk tájékoztatást kaptak a vizsgálat tárgyáról és menetérôl, a válaszadás önkéntességéról, adataik bizalmas kezelésérôl, illetve az anonimitásuk megôrzéséról. A kérdôívek kitöltését megelőzően a személyek beleegyezésüket adták a vizsgálatban való részvételhez.

\section{Eszközök}

\section{Megküzdési stílus}

A diszpozicionális megküzdést Endler és Parker (1994) Megküzdés Stresszhelyzetekben (CISS-48, Coping Inventory for Stressful Situations) skálájával mértük. A résztvevôk stresszt okozó helyzeteket felidézve válaszolták meg, hogy milyen mértékben jellemzôk rájuk az egyes tételek. Az állítássor 48 itemével a következô három megküzdési stílust méri: feladatorientált (pl. Jobban osztom be az idômet.), érzelemorientált (pl. Figyelmemet a saját bajaim kötik le.), és elkerülésorientált (pl. Megnézek egy filmet.) stílusok.

A skála eredetileg ötfokú Likert-skálát alkalmaz, azonban a differenciáltabb válaszok elérése érdekében hétfokú skálát használtunk (ahol 1: egyáltalán nem - 7: teljes mértékben jellemzô). Az itemsort Perczel Forintos Dóra és Annus Rita fordította magyarra (Perczel Forintos, Kiss és Ajtay, 2005).

Empirikus vizsgálatok során tesztelték a CISS három faktorának elkülönülését és pszichometriai mutatóit, melyek szerint a skála magas belsố konzisztenciával (Endler és Parker, 1990a, idézi Endler és Parker, 1994), valamint megfelelố megbízhatósággal bír (Rafnsson, Smari, Windle, Mears és Endler, 2006).

\section{Szociálisprobléma-megoldás}

A szociálisprobléma-megoldás mérésére az SPSI-R (Social Problem-Solving Inventory-Revised, D’Zurilla, Nezu és Maydeu-Olivares, 2002) skálát alkalmaztuk, melyet Kasik László és munkatársai (Kasik és mtsai, 2009) adaptáltak. A skála 25 állítással méri fel a szociálisprobléma-megoldás orientációját és az egyes megoldási stílusokat. A pozitív orientációt (pl. „Ha nem tudok elsôre megoldani egy problémát, nem adom fel.”), a negatív orientációt (pl. „Ha meg kell oldanom egy problémát, megijedek és félek.”); illetve a racionalitást (pl. „Döntés eloott végiggondolom minden lehetséges megoldás jó és rossz következményét.”), az impulzivitást (pl. „Ha döntenem kell, nem gondolom át alaposan a lehetôségeket.”) és az elkerülést (pl. „Várom, hogy a problémáim maguktól megoldódjanak, és ha nem, csak akkor próbálom én megoldani.”).

A vizsgálati személyek megjelölték, hogy megítélésük szerint milyen mértékben jellemzi óket az adott állítás úgy, hogy közben egy olyan problémát kellett felidézniük, amely az elmúlt három hónapban merült fel párjukkal, szüleikkel, csoporttársaikkal/ munkatársaikkal vagy oktatóikkal/feletteseikkel kapcsolatban (Kasik és mtsai, 2009).

Az állítássor ötfokú Likert-skálán mér, azonban az árnyaltabb válaszok elérése és a kérdőívcsomag egységessége érdekében hétfokú skálát alkalmaztunk ez esetben is (ahol 1: egyáltalán nem - 7: teljes mértékben jellemzó). 


\section{Viselkedéses szándékok}

A társadalmi problémák megoldására vonatkozó viselkedéses szándékokat a klímaváltozás, a természetes élôhelyek védelmének, a diabétesz, az egészséges életmód, a nélkülözó gyermekek helyzetének és a családon belüli erôszak megfékezésének témáiban mértük fel általunk megfogalmazott tételekkel. A vizsgálat eredményeinek ismertetésekor a hat témára a következô címkékkel utalunk: klíma, élóhely, diabétesz, életmód, gyerek és erószak. A témák kiválasztását korábbi vizsgálataink indokolják, melyekben hasonló problémákat felvonultató társadalmi célú reklámokat alkalmaztunk, ám a témák megítélésének összehasonlítására csak részben volt lehetôségünk.

A hat társadalmi nehézség a társadalmi célú üzenetek esetén megfigyelhetô három érdekcsoport mindegyikét lefedi: a klímaváltozás megelőzését és az élőhelyek megóvását szorgalmazó témák a társadalom; a diabétesz-szúrôvizsgálaton való részvételre és az egészséges életmód kialakítására ösztönzô üzenetek az egyén; míg a nélkülözô gyermekek megsegítésére és a családon belüli erôszak ellen való fellépésre buzdító témák a hátrányos helyzetben lévók érdekét szolgálják (Sas, 2010).

Mivel a szándékok mérése a vizsgálat központi részét képezi, minden tétel felsorolásra kerül:

- klíma: „A klímaváltozás megfékezése érdekében hajlandó vagyok tömegközlekedési eszközöket használni."

- élôhely: „Ami engem illet, tôlem telhetô módon a természetes élóhelyek állapotát megőrzöm azért, hogy ne jelenjenek meg a vadállatok a közterületeken.”

- diabétesz: „Hajlandó vagyok részt venni diabétesz-szúróvizsgálaton, hogy megelôzzem a cukorbetegség súlyos következményeit."

- életmód: „Idôt és pénzt áldozva hajlandó vagyok rendszeresen sportolni, hogy megôrizzem a lelki és fizikai jóllétemet."

- gyerek: „Kész vagyok humanitárius szervezeteknek adományozni, hogy ezzel változzon a nélkülözố gyermekek helyzete."

- erôszak: „Ha tudomásom van családon belüli erôszakról, kész vagyok bejelenteni azt, hogy ezzel megakadályozzam a további erőszakot.”

A vizsgálati személyek hétfokú Likert-skálán jelölték meg, hogy milyen mértékben értenek egyet az adott tételekkel (1: egyáltalán nem - 7: teljes mértékben egyetért).

\section{Demográfiai kérdések}

A kérdôívek zárásaként demográfiai adatokat mértünk fel a nemre, életkorra, lakhelyre, állampolgárságra, iskolai végzettségre, családi állapotra, illetve a gyermekek számára vonatkozóan.

\section{A vizsgálati minta}

A vizsgálatban 275 fố vett részt, 109 férfi és 166 nô; a válaszadók átlagéletkora 30 év $(\mathrm{sd}=11,38)$. A vizsgálati személyek mintája viszonylag heterogénnek tekinthetô végzettség szempontjából, de amint azt a 2. ábra szemléleti, a válaszadók nagy részét a felsôfokú és a gimnáziumi végzettséggel rendelkezôk adják. 


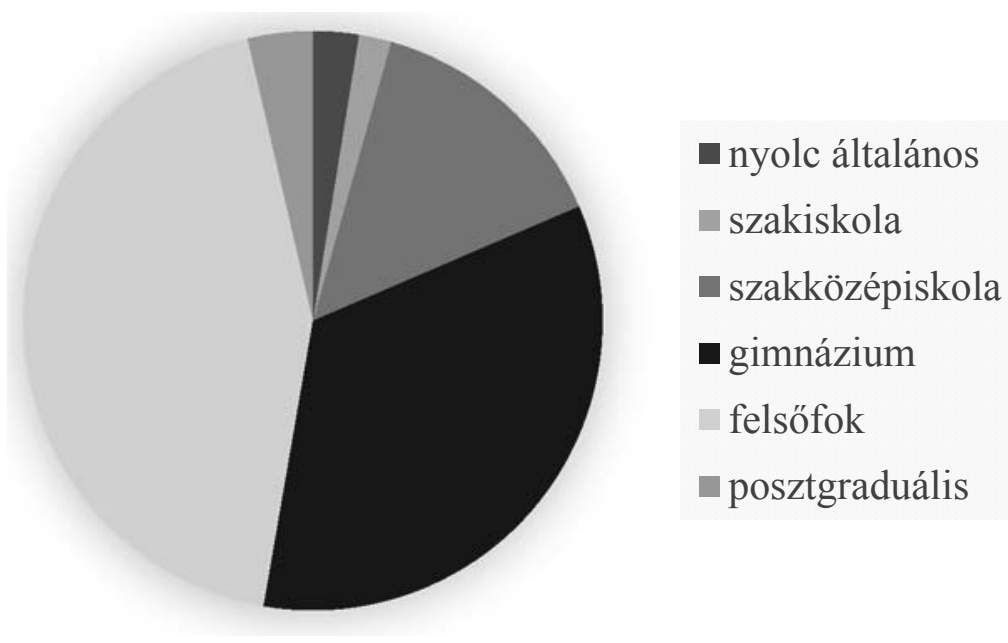

2. ábra. A vizsgálati minta végzettség szerinti megoszlása

\section{Etikai vonatkozások}

A vizsgálat a releváns kutatásetikai szempontokat figyelembe véve zajlott, az Egyesített Pszichológiai Kutatásetikai Bizottság által kiadott engedély száma: 2019/16.

\section{EREDMÉNYEK}

Az adatok összesítését követôen a leíró statisztikai elemzés részeként megbízhatóságvizsgálatot, a skálák számítási módjai alapján számolt értékeken normalitásvizsgálatot végeztünk. A statisztikai elemzést az $R$ program segítségével hajtottuk végre ( $R$ version -3.3.3, RStudio Team, 2016).

\section{Általános jellemzók}

A skálák jó, illetve magas belsố konzisztenciát mutattak. A CISS-48 skála feladatorientált alskáláján a Cronbach $\alpha$ megbízhatósági mutató 0,92, az érzelemorientált stílus esetén szintén $\alpha=0,92$; míg az elkerülésorientált dimenzión $\alpha=0,83$. A feladat- és érzelemorientált stílusok esetében vizsgáltuk az itemek közötti korrelációt, mely indokolhatja a 0,9 feletti $\alpha$-értéket. A feladatorientált megküzdés tételei között a legmagasabb r-érték 0,78, az érzelemorientált megküzdés állításai esetén 0,76. Ez alapján, bár vannak nagyon hasonló tételek, nem olyan mértékben egyezôek, hogy elhagyásuk indokolt lenne. A szociálisprobléma-megoldás skálájának megbízhatósága $\alpha=0,71$. A pozitív orientáció esetén $\alpha=0,62$, a negatív orientáció dimenzióján $\alpha=0,86$, a racionalitás megoldási módjára $\alpha=0,87$, az impulzivitás esetén $\alpha=0,7$, az elkerülő meg- 
oldási stílus dimenzióján $\alpha=0,86$. Összességében tehát a szociálisprobléma-megoldás skálájára is megfelelô megbízhatóság jellemzó.

Kolmogorov-Szmirnov-próbákkal a pontszámok normál eloszlását vizsgáltuk. A három megküzdési stílus esetében az értékek normális eloszlást mutattak, ez azonban nem volt jellemzô sem a szociálisprobléma-megoldás dimenziói, sem a szándékokra vonatkozó értékek esetén. Késôbb a normalitásvizsgálat eredményeinek megfelelô középértékekkel dolgoztunk. A skálákon elért pontszámok középértékeit és fố paramétereit az 1. táblázat foglalja össze.

1. táblázat. A skálákon elért pontszámok és a szándékértékek középértékei és paraméterei

\begin{tabular}{l|l|r|r|r}
\hline \multicolumn{2}{l|}{} & Átlag & Szórás & Medián \\
\hline Megküzdési stílus & Feladatorientált & 83,64 & 15,74 & 85 \\
& Érzelemorientált & 57,22 & 20,31 & 56 \\
Szociálisprobléma-megoldás & Elkerülésorientált & 51,75 & 15,78 & 51 \\
& Pozitív orientáció & 5,22 & 0,95 & 5,2 \\
& Negatív orientáció & 2,96 & 1,28 & 2,6 \\
& Racionalitás & 5,29 & 1,24 & 5,6 \\
Viselkedéses szándék & Impulzivitás & 3,24 & 1,09 & 3 \\
& Elkerülô stílus & 2,48 & 1,24 & 2,2 \\
& Klíma & 5,09 & 1,99 & 5 \\
& Éloóhely & 6,03 & 1,26 & 6 \\
& Diabétesz & 5,05 & 1,96 & 6 \\
& Életmód & 4,96 & 1,87 & 7 \\
& Gyerek & 4,31 & 1,86 & 5 \\
& Erôszak & 5,37 & 1,66 & 4 \\
\hline
\end{tabular}

\section{A hipotézisek vizsgálata}

Feltételeztük (H1), hogy a megküzdési stílusok és a viselkedéses szándékok összefüggnek. A hipotézis vizsgálatához Spearman-féle rangkorrelációkat végeztünk a különböző témákra vonatkozó szándékértékek és az egyes megküzdési stílusok pontszámai között. A szignifikáns kapcsolatokat a 2. táblázat foglalja össze.

2. táblázat. Az egyes témákra vonatkozó szándékértékek és a megküzdésistílus-pontszámok kapcsolata

\begin{tabular}{l|l|c|c|c}
\hline Megküzdési stílus & Probléma & rho & S & p-érték \\
\hline Feladatorientált & Élóhely & 0,31 & 2378600 & $<0,001$ \\
& Diabétesz & 0,17 & 2881700 & 0,005 \\
& Életmód & 0,16 & 2910500 & 0,008 \\
& Gyerek & 0,15 & 2929600 & 0,01 \\
& Erôszak & 0,16 & 2897200 & 0,006 \\
Érzelemorientált & Klíma & 0,13 & 3009700 & 0,03 \\
& Életmód & $-0,16$ & 4003600 & 0,01 \\
Elkerülésorientált & Klíma & 0,18 & 2838900 & 0,003 \\
\hline
\end{tabular}


Az összefüggések vizsgálatakor alapvetôen gyenge korrelációkat tapasztaltunk. A feladatorientált megküzdési stílus és a szándékértékek a klímaváltozás témáját kivéve minden esetben pozitívan korreláltak. Negatív összefüggés mutatkozott a klímaváltozás problémájára vonatkozó megoldási szándék és az érzelemorientált megküzdési stílus között. Ugyanakkor a klímaváltozás problémája esetén mindkét kevésbé adaptívnak tartott megküzdési mód gyenge, pozitív összefüggést mutatott a viselkedéses szándékkal. Az elsố hipotézis részben igazolódott, a feltárt mintázat nem teljesen szisztematikus.

Feltételeztük (H2), hogy a szociálisprobléma-megoldás dimenziói közül a pozitív problémaorientáció és a racionális megoldási mód pozitív kapcsolatot mutatnak a kedvezó szándékokkal. Ez esetben is Spearman-féle rangkorrelációkat hajtottunk végre, a szignifikáns kapcsolatokat a 3. táblázat tartalmazza.

3. táblázat. Az egyes témákra vonatkozó szándékértékek és a szociálisprobléma-megoldás dimenzióinak kapcsolata

\begin{tabular}{l|l|r|r|r}
\hline Dimenzió & Probléma & $\mathrm{r}$ & $\mathrm{S}$ & p-érték \\
\hline Pozitív orientáció & Élóhely & 0,18 & 2852300 & 0,003 \\
& Diabétesz & 0,16 & 2922400 & 0,009 \\
& Életmód & 0,22 & 2713200 & $<0,001$ \\
\multirow{4}{*}{ Negatív orientáció } & Erószak & 0,27 & 2535600 & $<0,001$ \\
& Éloohely & $-0,16$ & 4031000 & 0,007 \\
& Életmód & $-0,19$ & 4118900 & 0,002 \\
Racionalitás & Erôszak & $-0,14$ & 3962300 & 0,02 \\
& Élóhely & 0,21 & 2748300 & $<0,001$ \\
& Diabétesz & 0,2 & 2759600 & $<0,001$ \\
& Életmód & 0,17 & 2865300 & 0,004 \\
Elkerülés & Gyerek & 0,17 & 2863700 & 0,004 \\
& Erószak & 0,15 & 2929100 & 0,01 \\
& Élóhely & $-0,13$ & 3921100 & 0,03 \\
& Életmód & $-0,13$ & 3929600 & 0,03 \\
& Gyerek & $-0,13$ & 3913000 & 0,03 \\
\hline
\end{tabular}

Az eredményeket tekintve a szignifikáns kapcsolatok pozitív irányúak voltak a probléma megoldásához közelítô pozitív orientáció és racionalitás dimenzióin, ezzel párhuzamosan pedig negatívak a problémamegoldást hárító negatív orientáció és az elkerülés mint megoldás mód dimenziói esetében. A hipotézis azonban csak részben tartható, mert az eredmények nem jelentkeztek minden vizsgált téma esetén.

\section{Kiegészitó eredmények}

A hipotézisek vizsgálatakor a konstruktumok alapvetô összefüggései mutatkoztak meg, azonban szisztematikusságuk hiányában további elemzéseket végeztünk: a változók kapcsolatát már nem egyszerú lineáris összefüggéseket feltételezve közelítettük meg. 


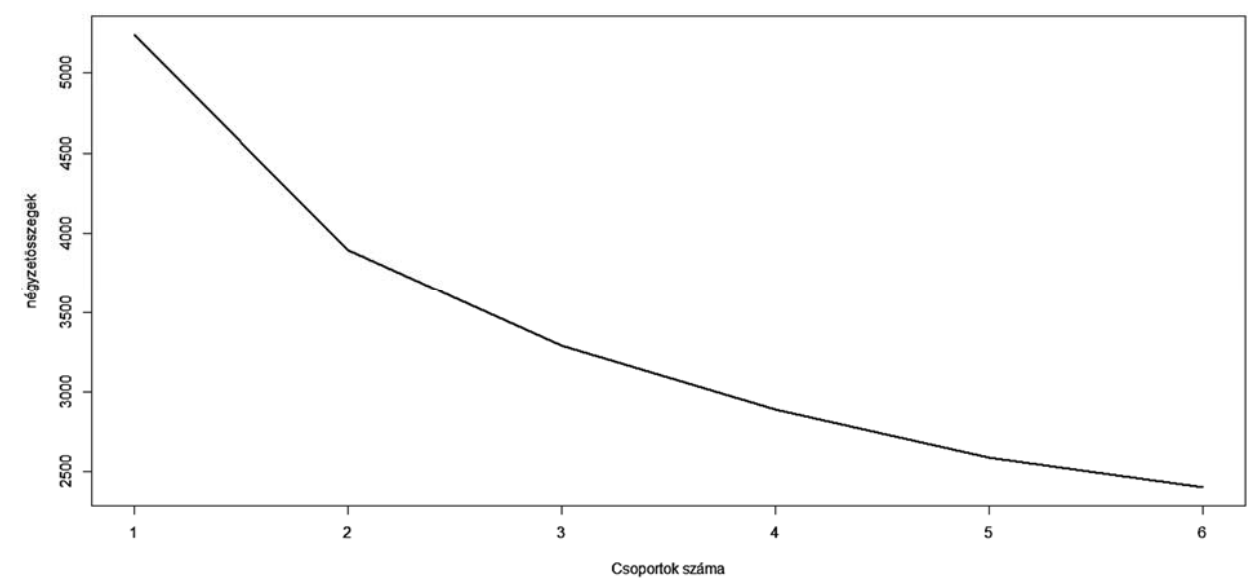

3. ábra. A K-középpontú klaszteranalízisek eredményeként a csoporton belüli négyzetösszegek

Mivel úgy tûnt, az egyes társadalmi problémák jellege meghatározó a viselkedési szándékra vonatkozóan, a szándékértékekre K-középpontú klaszteranalízist végeztünk. A különbözô klaszterszám mellett tapasztalt csoporton belüli négyzetösszegek által megrajzolt grafikont a 3. ábra mutatja.

A klaszterek által kijelölt csoportok számának meghatározásához a könyökszabályt alkalmaztuk. Amint az a 3. ábra alapján is látható, a háromklaszteres megoldás a heterogenitást jelentôsen csökkenti (annak ellenére, hogy nagyobb törés a kétklaszteres megoldás esetén figyelhetô meg). Így arra következtettünk, hogy a problémákra vonatkozó megoldási szándékaik alapján a személyek három csoportja különíthetô el. Eszerint az elsố csoportba 75, a másodikba 130, a harmadikba pedig 70 személy tartozik.

Khi-négyzet-próbákat végrehajtva vizsgáltuk a csoportok közötti különbségeket demográfiai változók mentén. A csoportok nem térnek el a nem $\left(\chi^{2}=3,11, \mathrm{df}=2, \mathrm{p}=\right.$ $0,21)$, a végzettség $\left(\chi^{2}=8,34, \mathrm{df}=10, \mathrm{p}=0,6\right)$ és a családi állapot $\left(\chi^{2}=15,64, \mathrm{df}=10, \mathrm{p}=\right.$ $0,11)$ tekintetében. Az életkor alapján azonban a csoportok közötti különbség kicsi, ám szignifikáns (Kruskal-Wallis-próba eredménye: $\chi^{2}=16,19$, df $=2, p<0,001$ ). Az elsố csoport esetében 26,5, a második csoportban 30,6, míg a harmadik csoport esetén 33,4 év az átlagéletkor.

A három csoportra jellemzô, a különbözô társadalmi problémákkal kapcsolatos viselkedéses szándékok középértékeit a 4. ábra illusztrálja.

Hogy az azonos témákra jelölt szándékértékek eltérôek-e a csoportok között, Kruskal-Wallis-próbákkal vizsgáltuk, mely próbák minden téma esetében a csoportok szignifikáns különbségét jelezték $\left(\chi_{\text {min }}^{2}=19,34, \chi_{\text {max }}^{2}=132,47\right.$; p-érték rendre <0,001).

Mann-Whitney-próbákkal páros összehasonlításokat végeztünk. Nem tapasztaltunk szignifikáns eltéréseket az elsô és harmadik csoport között az élóhelyek védelme $(\mathrm{W}=2516,5, \mathrm{p}=0,65)$, a második és a harmadik csoport között az egészséges életmód témája ( $\mathrm{W}=4757, \mathrm{p}=0,58$ ), valamint a második és a harmadik csoport között az erô- 


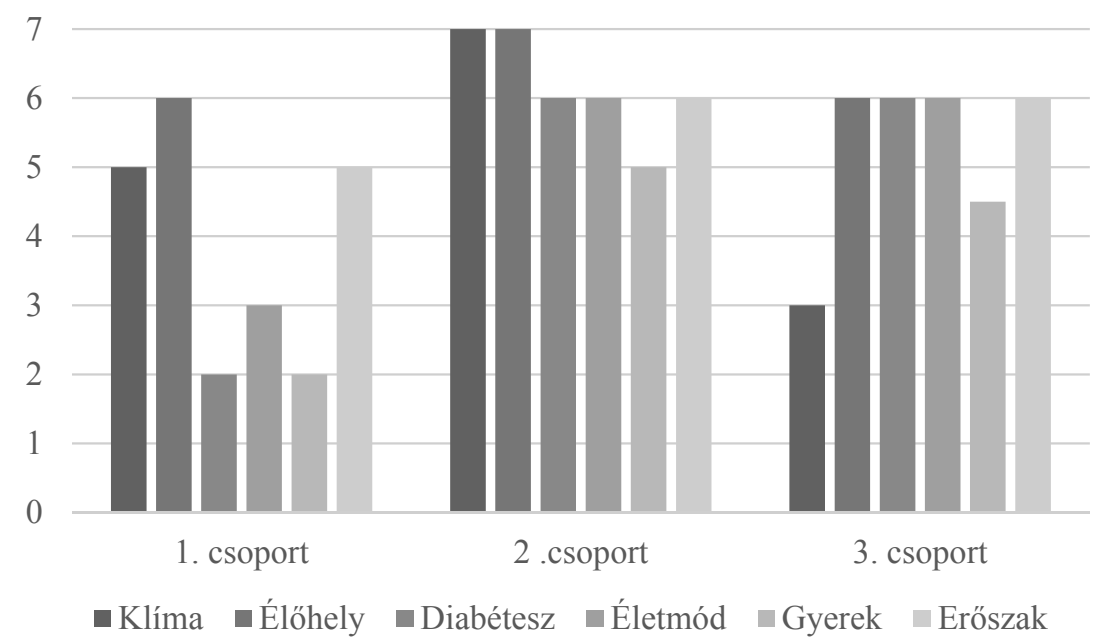

4. ábra. A klaszteranalízis útján létrejövố csoportok viselkedéses szándékokra jelölt középértékei témánként

szakkal sújtottak megsegítésének szándéka $(\mathrm{W}=5160, \mathrm{p}=0,1)$ esetében. Minden további összevetés szignifikáns volt $\left(\mathrm{W}_{\min }=504, \mathrm{p}<0,01\right)$.

Úgy tûnik, hogy a vizsgálati személyek elsố csoportja elsôsorban a környezetvédelem és a családon belüli erôszak áldozatainak védelme esetében jelöl magas pontszámokat. A válaszadók második csoportja csaknem minden társadalmi nehézség tekintetében magas értékeket jelölt meg. A harmadik csoportba tartozók valamivel alacsonyabb értékeket jelölnek, mint a második csoport, de ezek magasabbak az elsô csoport értékeihez képest. Ez alól kivétel a klímaváltozás problémája, ahol esetükben a legalacsonyabbak az értékek.

Ha alaposabban szemügyre vesszük a természetes élôhelyek védelmére vonatkozó kérdést, akkor azt látjuk, hogy nem igazán differenciál a csoportok között a témára vonatkozó szándék. A leginkább differenciáló témáknak a klíma, a diabétesz, az életmód és a gyerek címkékkel ellátott kérdések tûnnek. Azon tételek, melyek a személyre vagy közvetlen környezetére vonatkoznak (életmód, diabétesz, gyerek), úgy tûnik, mintha együtt mozogva magas vagy alacsony értéket vennének fel.

A csoportok ismeretében másként vizsgáltuk a szándékok és a megküzdés, valamint a szándékok és a szociálisprobléma-megoldás kapcsolatait. Egyszempontos varianciaanalízissel vizsgáltuk, hogy a csoportok szándékértékei összefüggnek-e a megküzdési stílusokkal. Az eredmény szignifikáns volt a feladatorientált stílus $[\mathrm{F}(2,272)=6,6$, $\mathrm{p}=0,002]$, az érzelemorientált megküzdés $[\mathrm{F}(2,272)=3,86, \mathrm{p}=0,02]$ és az elkerülésorientált stílus esetén is $[\mathrm{F}(2,272)=4,07, \mathrm{p}=0,018]$. A három csoport által a különbözô megküzdési stílusokon felvett átlagértékeket a 4. táblázat tartalmazza. A páronkénti eltéréseket Bonferroni-próbákkal vizsgáltuk.

Az elsố csoport, amelybe tartozó személyek elsôsorban a klímaváltozás, a természetes éloohelyek védelme és a családon belüli erôszak témáiban jelöltek magasabb szándékokat, 
4. táblázat. Az egyes megküzdésistílus-pontszámok a szándékok szerint rendezôdô csoportok által elért átlagértékei

\begin{tabular}{l|c|c|c}
\hline & Feladatorientált & Érzelemorientált & Elkerülésorientált \\
\hline 1. csoport & 78,19 & 60,03 & 49,53 \\
2. csoport & 86,12 & 58,66 & 54,58 \\
3. csoport & 84,89 & 51,54 & 48,89 \\
\hline
\end{tabular}

a feladatorientált megküzdési stílus alacsonyabb mértékével jellemezhetô $(\mathrm{p}<0,028)$. A csoportra jellemzó az érzelemorientált megküzdés a második csoporttal azonos $(\mathrm{p}>0,05)$; a harmadik csoporthoz képest $(\mathrm{p}<0,035)$ pedig magasabb mértékben.

A második csoport vizsgálati személyei, akik nagyjából minden felvonultatott társadalmi probléma megoldására kedvezô szándékokat jelöltek, mindhárom megküzdési stílus magas szintjével jellemezhetôk. A feladatorientált megküzdéssel az elsô csoportnál nagyobb $(\mathrm{p}<0,001)$ és a harmadik csoporttal azonos mértékben $(\mathrm{p}>0,05)$; az érzelemorientáltsággal az elsố csoporttal azonos ( $\mathrm{p}>0,05)$, de a harmadik csoportnál nagyobb mértékben $(\mathrm{p}<0,035)$. Az elkerülésorientációval mindkét csoporthoz képest fokozottabb mértékben $(\mathrm{p}<0,08)$ rendelkeznek e csoport tagjai.

A harmadik csoportba tartozó személyek a klímaváltozás problémáján kívül minden témára közepesen magas szándékértékeket jelöltek. Fóként a feladatorientált megküzdéssel és minden más megküzdési stílus egy alacsonyabb szintjével rendelkeznek (érzelemorientáció $\mathrm{p}<0,05$; elkerülésorientáció $\mathrm{p}<0,05$ ).

Összességében tehát megállapítható, hogy ugyan a csoportok létrejöttének alapját a társadalmi nehézségek megoldására irányuló szándékok adják, mégis, a csoportok a háromféle megküzdési stílus eltérô mértékeivel jellemezhetôk.

A három csoport szociálisprobléma-megoldás dimenzióinak esetében hasonlóan jártunk el, Kruskal-Wallis-próbákat alkalmaztunk. A csoportok középértékei szignifikánsan eltértek a pozitív orientáció $\left(\chi^{2}=12,27, \mathrm{df}=2, \mathrm{p}=0,002\right)$, a racionalitás $\left(\chi^{2}=\right.$ $10,32, \mathrm{df}=2, \mathrm{p}=0,006)$ és az elkerülés $\left(\chi^{2}=13,95, \mathrm{df}=2, \mathrm{p}<0,001\right)$ dimenzióinál. A negatív orientáció esetén tendenciaszerú eltérés mutatkozott $\left(\chi^{2}=5,69, \mathrm{df}=2, \mathrm{p}=0,06\right)$, míg az impulzivitás esetében nem tapasztaltunk szignifikáns eltérést $\left(\chi^{2}=0,203\right.$, df $=$ $2, \mathrm{p}=0,90)$. A három csoport által a szociálisprobléma-megoldás dimenzióin elért középértékeket az 5. ábra illusztrálja.

Mann-Whitney-próbákkal a csoportok páros összehasonlítását elvégezve az 5. táblázatban összefoglalt szignifikáns különbségeket tapasztaltuk a csoportok között.

A szociálisprobléma-megoldás képességének szempontjából az elsố csoport a pozitív orientáció és a racionalitás, tehát a probléma hatékony megoldásának egy alacsonyabb szintjével jellemezhetô; míg a csoport tagjai a negatív orientáció és az impulzivitás, valamint az elkerülés tekintetében érnek el magas értékeket (a többi csoportéhoz viszonyítva). Ôk azok a személyek, akik fooként a közösség érdekében megoldandó klímaváltozás és éloohelyvédelem, valamint az erószak megoldása kapcsán jelölnek fokozott szándékokat. A második csoport, melynek tagjai minden nehézség megoldására hasonlóan magas szándékot mutatnak, a racionális problémamegoldás, a probléma iránti pozitív odafordulás magas szintjével rendelkeznek. A harmadik csoportba tartozó 


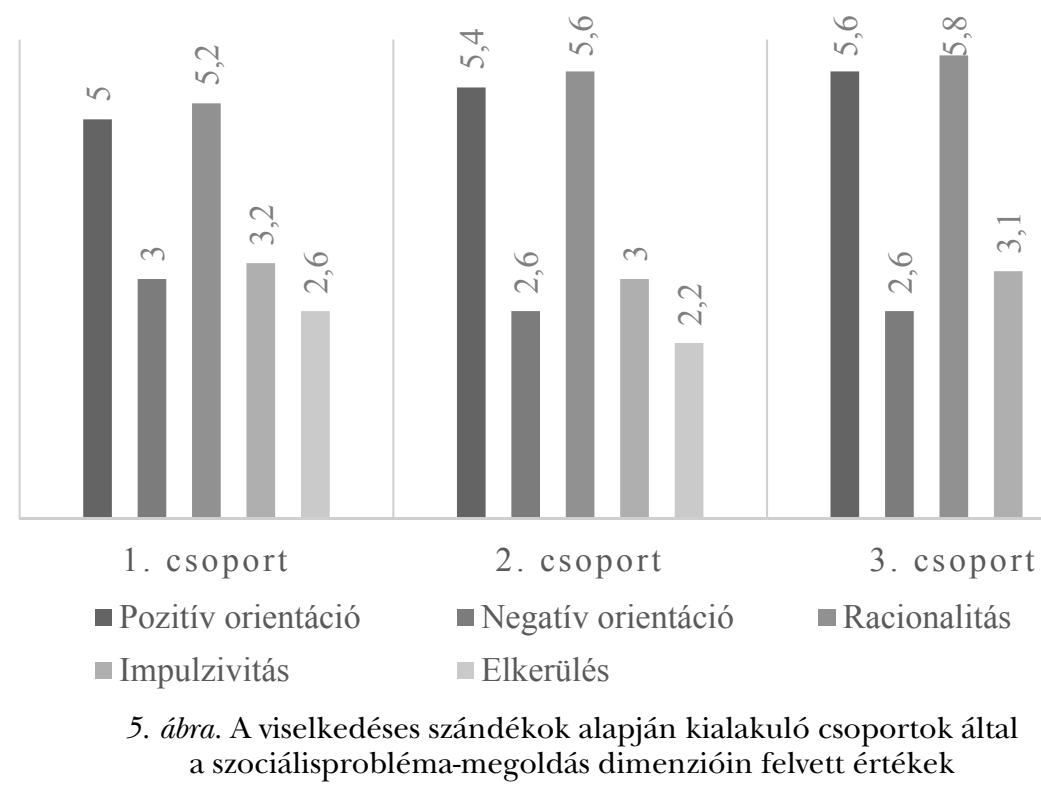

5. táblázat. A megoldási szándékok szerint elkülönülố csoportok között a szociálisproblémamegoldás dimenzióin tapasztalt eltérések

\begin{tabular}{lcr}
\hline \multirow{2}{*}{ Pozitív orientáció } & Csoportok & $\mathrm{W}$ \\
& elsô - második & $3751^{* *}$ \\
Negatív orientáció & elsô - harmadik & $1783,5^{* * *}$ \\
Racionalitás & elsô - harmadik & $3205,5^{*}$ \\
& elsố - második & $3834,5^{* *}$ \\
Elkerülés & elsô - harmadik & $1871,5^{* *}$ \\
& elsố - második & $5866,5^{*}$ \\
& elsô - harmadik & $3517 * * *$ \\
$*-\mathrm{p}<0,05, * *-\mathrm{p}<0,01, * * *-\mathrm{p}<0,001$ & $5336^{*}$ \\
\hline
\end{tabular}

személyek, akik alapvetôen elfogadónak tûnnek a társadalmi nehézségek megoldási módjait illetôen - a klímaváltozás kérdését kivéve -, a pozitív orientáció és a racionalitás magas, továbbá az elkerülés alacsony szintjével jellemezhetôk.

A csoportok között tapasztalt eltérések mentén diszkriminanciaanalízis segítségével vizsgáltuk, hogy a megküzdési stílus és a szociálisprobléma-megoldás változói alapján bejósolható-e, hogy milyen „profillal” rendelkezik egy személy; azaz milyen szándékok jellemzik ôt a társadalmi nehézségek megoldására vonatkozóan. A diszkriminanciaanalízis prediktív változóiként azokat a tényezóket vettük figyelembe, melyek esetén különbség mutatkozott a varianciaanalízis vagy a Kruskal-Wallis-próbák eredményei szerint. Nyilvánvalóan nem ezek az egyetlen tényezók, melyek a társadalmi problémák megoldásában való együttmúködésre vonatkozó szándék tekintetében fontosak, de hatásuk megítélését ez az elemzés is segítheti. 
A diszkriminanciaanalízis modelljébe így együttesen a megküzdési stílus három és a szociálisprobléma-megoldás négy dimenzióját illesztettük. Az eredmények alapján az elsố csoportba tartozást valószínúsíti a feladatorientált megküzdés közepes $(78,19)$ és az érzelemorientált megküzdés magas $(60,03)$ szintje, illetve a közepesen magas pozitív orientáció $(4,87)$, racionalitás $(4,93)$, és a negatív orientációnak is egy közepes mértéke $(3,26)$. A második csoportba tartozás akkor valószínúsíthetô, ha az illetốre jellemzó a feladatorientált megküzdés magas szintje $(86,12)$ és a fokozott elkerülésorientált megküzdés $(54,58)$, ehhez pedig magas szintú pozitív orientáció $(5,29)$ és racionalitás $(5,36)$ társul; illetve viszonylag alacsony negatív orientáció $(2,94)$. A harmadik csoportba várhatóan azon személyek tartoznak, akik nem túl magas feladatorientált megküzdéssel bírnak $(84,89)$, ám ehhez az érzelem- és elkerülésorientált megküzdések alacsony szintje kapcsolódik (rendre 51,54 és 48,89) úgy, hogy közben igen magas a pozitív orientáció $(5,44)$ és a racionalitás $(5,55)$. Mindemellett esetükben kismértékú a negatív orientáció $(2,65)$ és az elkerülő szociálisprobléma-megoldó stílus $(2,13)$.

A megfigyelt csoporttagság és a modell alapján bejósolt tagság összevetése alapján a helyes besorolási arány $53 \%$. A modellben szereplő tényezôk súlyát figyelembe véve azonban megállapítható, hogy elsôsorban a szociálisprobléma-megoldás tényezôi lényegesek a csoportba sorolás bejóslásához, amint ez a 6. táblázatból is kiderül.

6. táblázat. A diszkriminanciaanalízis modelljében szereplő tényezôk súlya

\begin{tabular}{l|c|c}
\hline & LD1 & LD2 \\
\hline Feladatorientált megküzdés & $-0,014$ & $-0,057$ \\
Érzelemorientált megküzdés & $-0,002$ & $-0,04$ \\
Elkerülésorientált megküzdés & 0,03 & $-0,03$ \\
Pozitív orientáció & 0,42 & 0,37 \\
Negatív orientáció & $-0,14$ & 0,2 \\
Racionalitás & 0,336 & 0,48 \\
Impulzivitás & $-0,53$ & 0,2 \\
\hline
\end{tabular}

Amennyiben elhagyjuk a megküzdési stílus tényezôit és csak a szociálisprobléma-megoldás által történô csoportba sorolást vesszük figyelembe, a szúkített modell és a megfigyelt csoporttagság összevetése szerint a helyes besorolási arány $51 \%$.

\section{DISZKUSSZIÓ}

A tanulmányban bemutatott vizsgálat célja a társadalmi problémák megoldására vonatkozó viselkedéses szándékok felmérése a jellemzô megküzdési stílus és a szociálisprobléma-megoldó képesség függvényében. A felvonultatott társadalmi nehézségek a klímaváltozásra, a természetes éloohelyek védelmére, a diabétesz-szúrôvizsgálatra, az egészséges életmódra, a nélkülözô gyermekek megsegítésére, valamint a családon belüli erôszak megelôzésére vonatkoztak. Ezek a társadalmi problémák jelentôsen különböznek egymástól a tekintetben, hogy kinek az érdekét szolgálja megoldásuk: az egyénét, egy másik személyét/csoportét vagy hosszú távon a teljes társadalomét. Korábbi 
vizsgálatainkból kiindulva merült fel az igény, hogy mindhárom érdeket együtt, egymással összehasonlítva tárgyaljuk, ezúttal a konkrét reklámok vizsgálatát nélkülözve.

A vizsgálat egyik alapfeltevése volt, hogy a feladatorientált megküzdési stílus alkalmazása a társadalmi problémák megoldására vonatkozó magasabb szándékokkal kapcsolódik össze. Feltételeztük továbbá, hogy a társadalmi problémák megoldásának szándéka együtt jár a szociálisprobléma-megoldás pozitív orientációjával és a racionális megoldási móddal.

Kezdetben lineáris összefüggéseket vizsgálva, gyenge, de szignifikáns együtt járásokat tapasztaltunk; azonban ezek nem voltak szisztematikusak a különbözó társadalmi problémák esetében. A hipotézisek vizsgálatának nem lineáris megközelítésével ugyanakkor a személyek három csoportját tudtuk azonosítani a társadalmi nehézségek megoldására vonatkozó szándékaik alapján. Egy csoportot, amelynek tagjai a kimenetet tekintve a személyesen kevésbé kontrollálható - a klímaváltozással, az élôhelyek védelmével és az erôszak megelôzésével kapcsolatos - nehézségek iránt magas szándékokat mutattak. Egy másik csoportot, melynek tagjai csaknem minden problémát illetôen magas szándékokkal rendelkeztek, különösen a klímaváltozás és az élôhelyek megóvása kapcsán. Továbbá egy harmadik csoportot, melynek tagjai fơként az énközeli problémákra, nevezetesen a diabétesz-szúrôvizsgálaton való részvételre és az egészséges életmódra; valamint az erôszak megelőzésére fejeztek ki magas szándékokat.

A három csoport az életkor tekintetében is elkülönült. Azon személyek, akik elsôsorban a közösség érdekeit szolgáló témák megoldására jeleztek magas szándékokat, a 26 év körüli fiatal felnôttek korosztályába tartoztak. Azok, akik szinte minden felvonultatott probléma megoldására hajlandóak voltak, a 30 év körüli érett felnôttek korcsoportjába sorolhatók. A harmadik csoportba tartozó személyek, akik legkevésbé hajlandóak tenni a klímaváltozás ügyében, de minden más ügy érdekében viszonylag magas szándékokat fejeztek ki, a 33 év körüli, tehát az idôsebb érett felnôttek csoportját képezik. Mivel a problémák megoldásának szándéka szerint alakuló csoportok a jellemzố megküzdési stílusok és a szociálisprobléma-megoldás bizonyos faktorai alapján szintén elkülönültek, az eredményeket e tekintetben is érdemes megvitatni.

Folkman, Lazarus, Pimley és Novacek (1987) 35 és 45 év közötti érett, valamint 65 és 74 év közötti idôs felnôttek csoportjaiban vizsgálták a szituatív probléma- és érzelemfókuszú megküzdési stratégiákat, azt tapasztalva, hogy az érett felnôttek csoportjában elsôsorban a probléma megoldására, a megoldás tervezésére irányuló megküzdési módok fordultak elô. Blanchard-Fields és Irion (1988) fiatal és érett felnôttek korosztályaiban tanulmányozták a probléma- és érzelemfókuszú megküzdési stratégiákat, kitérve a helyzet felett észlelt szubjektív kontroll kérdésére is. Eredményeik szerint a felnôttkort elérve a problémafókuszú megküzdési stratégiák alkalmazási gyakorisága nôtt a kontrollálható kimenetû helyzetekben: a fiatal felnôttek esetében fordult elô leggyakrabban, érett felnôttkorra csökkent a mértéke. Az érzelemfókuszú és védekezô megküzdések elsôsorban a fiatalabb személyeket jellemezték, a kontroll mértékétôl függetlenül.

Vizsgálatunkban ugyan a diszpozicionális feladat-, érzelem- és elkerülésorientált megküzdési stílusokat tanulmányoztuk Endler és Parker (1994) nyomán, a viselkedéses szándékokon alapuló csoportok hasonló mintázatokat mutattak a megküzdést illetôen. A fiatal felnôttekbôl álló csoportban valóban kiugró az érzelemorientált stílus 
mértéke, illetve alacsonyabb a feladatorientált megküzdés szintje. Az átlagosan 30 éves érett felnôttekre kevésbé jellemzô az érzelemorientált megküzdés, azonban a feladatorientált stílus esetükben a legmagasabb; míg a 33 év körüli felnôttek csoportjában a legkisebb mértékú az érzelem- és elkerülésorientált megküzdések elôfordulása. Eszerint, életkori tényezók is szerepet játszhatnak az alapvetôen a problémák megoldására vonatkozó viselkedéses szándékaik alapján elkülönített csoportok jellemzô megküzdési mintáiban.

A szociálisprobléma-megoldás és az életkor összefüggését illetôen D'Zurilla, Maydeu-Olivares és Kant (1998) az SPSI-R mérôeszközét alkalmazva megállapították, hogy a szociálisprobléma-megoldó teljesítmény nố az életkor elôrehaladtával, fiatal felnôttkortól a középkorig, majd idôskorban hanyatlik. Eredményeik azt mutatták, hogy a pozitív problémaorientáció és a racionális problémamegoldás, tehát a konstruktív dimenziók magasabb szintje jellemzô középkorban; és ezzel párhuzamosan a negatív orientáció, az impulzivitás és az elkerülés stílusai kisebb mértékúek. Jelen vizsgálatban azonosított csoportok D'Zurilla és munkatársai tanulmánya mentén a fiatal felnôtt korcsoportnak feleltethetôk meg, az általuk megfigyelt mintázatok mintánk három csoportjában is azonosíthatók.

Úgy tûnik, hogy az életkor, a megküzdési stílus és a szociálisprobléma-megoldás változói összefüggnek, az utóbb említett két konstruktum szempontjából pedig az észlelt kontroll mértéke is számíthat. A változók között vélhetô ok-okozati viszonyok feltárása további vizsgálatokat implikál.

Az eredmények alapján úgy tûnik, hogy a társadalmi nehézségek természetének különbözôsége befolyásoló tényezô a szándékok alakulásában. E kapcsolatban az életkori szempontból lényeges érintettség közvetítô változóként múködhet. Az érintettség a meggyôzés Heurisztikus-Szisztematikus Feldolgozási Modelljének (Chaiken, 1980) központi eleme, valamint Kim Witte (1992) a félelemkeltô meggyôzés kognitív feldolgozását tárgyaló elméletének az észlelt fogékonyság faktorába ágyazódik. Az érintettség jelentôsége, hogy kihat a meggyôzô üzenetben tartalmazott információ feldolgozására (Chaiken, 1980) és általa a befogadó dönteni képes arról, hogy a fenyegetés, probléma rá nézve releváns-e (Witte, 1992). Végeredményben ezek az üzenet hatékonyságát, a meggyôzés sikerességét befolyásolják. Az érintettség, fogékonyság alacsony szintje mellett a meggyôzés sikertelen, vagy csak felületes lehet (Chaiken, 1980). Jelen esetben a kívánatos viselkedéses szándékok kialakítására fókuszáltunk, azonban mivel a szándék a viselkedés akár közvetlen elôzménye lehet (Ajzen, 1991), az érintettség kérdése ez esetben is releváns lehet.

A fiatal felnôttek alkotta csoport a diabétesz-szúrôvizsgálaton való részvételre, az egészséges életmód kialakítására vagy a nélkülözó gyermekek megsegítésére vonatkozó alacsony szándékát befolyásolhatja, hogy e korcsoport számára ezek kevéssé releváns problémák. A diabétesz kialakulásának kockázatát és a hosszú távú, nemkívánatos egészségügyi következményeket kevéssé valószínúnek észlelhetik, illetve a gyerekvállalás átlagosan alacsony gyakorisága miatt egyaránt távoli lehet számukra a gyermekek nélkülözésének kérdése.

Az érett felnôttekbốl álló csoport alacsonyabb szándékot fejez ki a tömegközlekedési eszközök használata kapcsán. Ennek alapja lehet, hogy a csoportba tartozók kevéssé szorulhatnak tömegközlekedés használatára; ugyanakkor az is felmerülhet, hogy az 
idősebb korosztály tekinthet úgy a közösségi érdekeket szolgáló problémákra (klímaváltozás, élôhelyvédelem), mint amelyek következményei idôben távoliak, így irrelevánsak rájuk nézve. A cukorszúrés és az egészséges életmód kialakítása mint egészségügyi kockázatokat közvetítô kérdések azonban esetükben már lényegesként foghatók fel a kor elôrehaladtával.

A vizsgálat egyik alapvetô célja az volt, hogy a különbözố társadalmi problémákra irányuló szándékok összevethetôségét segítse. Végeredményben azonban azt tapasztaltuk, hogy az érdekek nem befolyásolták az eredményeket, nem volt hatásuk a szándékok szerint rendezôdô csoportok alakulására. Az érintettségen túl maguk a társadalmi problémák és azok társas megítélése is fontos módosító tényezôként múködhetnek. A klímaváltozás megfékezésére javasolt tömegközlekedésieszköz-használat például egy szokáscselekvés, mely már önmagában is az erre vonatkozó meggyôzési, attitûdváltozási folyamatok külön módozatát képezi. A problémák társas megítélését nem állt módunkban vizsgálni, azonban fontos számolni a tényezó potenciális szerepével a változók közötti kapcsolatokat illetôen; ez egyben jelen vizsgálati eredmények értelmezésének limitációját is képezi.

Az élőhelyvédelem problémáját tekintve, talán nem a legmegfeleloobb negatív következmény került felvázolásra a vadállatok közutakon való megjelenésének említésével, hiszen valószínûségét tekintve ennek kockázata alacsony, és számos más tényezô is befolyásolhatja. Ebből is fakadhat, hogy az élőhelyvédelemre vonatkozó szándékok a vizsgálati minta három csoportjában nem tértek el jelentôsen.

A családon belüli erôszak ellen való fellépés problémája sem differenciálta igazán a vizsgálati személyek három csoportját a szándék tekintetében. Ez esetben eltérô megítélést okozhat a többi nehézséghez képest a probléma fokozott jogi, etikai szabályozottsága.

Ami a szociálisprobléma-megoldás konstruktumát illeti, a megküzdéssel ismert összefüggései (D’Zurilla és Nezu, 2007, idézi Kasik, 2015) révén is illesztettük vizsgálatunkba. A szociálisprobléma-megoldás dimenziói az eredmények alapján többnyire követték a megküzdési stílusok szerint alakuló mintázatokat: a pozitív problémaorientáció együtt mozgott a feladatorientált megküzdési stílussal, míg a negatív orientáció és a hozzá tartozó megoldási stílusok jobbára az érzelem- és elkerülésorientált megküzdések értékeivel párhuzamosan alakultak. A szociálisprobléma-megoldás mérésének fontosságára rámutat a diszkriminanciaanalízis eredménye, mely szerint a pozitív és negatív problémaorientációk, illetve a racionalitás és az elkerülés dimenziói lényeges bejóslói a szándékok alapján rendezôdô csoporttagságoknak. El kell ismernünk azonban, hogy a szociálisprobléma-megoldás vizsgálata és annak az SPSI-R skálán keresztül történô mérése többnyire a fejlôdéslélektani, iskolapszichológiai (például hátrányos helyzetûekkel foglalkozó), illetve személyiségpszichológiai kutatások tárgyát képezi, a személyközi problémák és konfliktusok megoldására fókuszálva (pl. Kasik, 2015). A társadalmi szintû nehézségek megoldásának tanulmányozása így nem sorolható a szociálisprobléma-megoldással foglalkozó kutatások jellemzô körébe. Mindez a tanulmányban közölt vizsgálat megközelítésének újszerúségét, ugyanakkor annak limitációját is jelenti.

A vizsgálat eredményeit összegezve egyik fố következtetésünk, hogy a társadalmi problémákra irányuló attitúdök tanulmányozását érdemes lehet az életkor és az álta- 
lános problémamegoldás szempontjából megközelíteni. A továbbiakban érdemes lehet az eltérô társadalmi célokra vonatkozó megoldási szándékok különálló vizsgálata. A további kutatások kiterjeszthetôk a szubjektív kontroll és az érintettség tényezóinek tanulmányozásával.

\section{KÖSZÖNETNYILVÁNÍTÁS}

A publikáció elkészítését az EFOP-3.6.1-16-2016-00022 számú projekt támogatta. A projekt az Európai Unió támogatásával, az Európai Szociális Alap társfinanszírozásával valósult meg.

\section{IRODALOM}

Ajzen, I. (1991). The Theory of Planned Behavior. Organizational Behavior and Human Decision Processes, 50, 179-211. doi: 10.1016/0749-5978(91)90020-T

Ajzen, I., \& Fishbein, M. (2005). The influence of attitudes on behavior. In Albaraccín, D., Johnson, B. T., Zanna, M. P. (Eds), The handbook of attitudes (pp. 173-221.). Mahwah, NJ: Lawrence Erlbaum Associates, Publishers.

Blanchard-Fields, F., \& Irion, J. C. (1988). The relation between locus of control and coping in two contexts: Age as a moderator variable. Psychology and Aging, 3(2), 197-203. doi: 10.1037/0882-7974.3.2.197

Carver, C. S., \& Scheier, M. F. (1994). Situational coping and coping dispositions in a stressful transaction. Journal of Personality and Social Psychology, 66(1), 184-195. doi: 10.1037//00223514.66.1.184

Chaiken, S. (1980). Heuristic versus systematic information processing and the use of source versus message cues in persuasion. Journal of Personality and Social Psychology, 39(5), 752-766. doi: 10.1037/0022-3514.39.5.752

Conway, V. J., \& Terry, D. J. (1992). Appraised controllability as a moderator of the effectiveness of different coping strategies: A test of the goodness of fit hypothesis. Australian Journal of Psychology, 44(1), 1-7. doi: 10.1080/00049539208260155

D'Zurilla, T. J., \& Chang, E. C. (1995). The relations between social problem solving and coping. Cognitive Therapy and Research, 19(5), 547-562. doi: 10.1007/BF02230513

D'Zurilla, T. J., Maydeu-Olivares, A., \& Kant, G. L. (1998). Age and gender differences in social problem-solving ability. Personality and Individual Differences, 25(2), 241-252. doi: 10.1016/ S0191-8869(98)00029-4

D'Zurilla, T. J., \& Nezu, A. M. (1982). Social problem solving in adults. In Kendall, P. C. (Ed), Advances in cognitive-behavioral research and therapy (pp. 201-274.). New York: Academic Press.

D'Zurilla, T. J., \& Nezu, A. M. (2007). Problem-solving therapy: A positive approach to clinical Intervention. NY: Spring Publishing Company.

D’Zurilla, T. J., Nezu, A. M., \& Maydeu-Olivares, A. (2002). Social Problem-Solving Inventory-Revised (SPSI-R): Technical manual. North Tonawanda. NY: Multi-Health Systems.

D'Zurilla, T. J., Nezu, A. M., \& Maydeu-Olivares, A. (2004). Social problem solving: Theory and assessment. In Chang, E. C. D'Zurilla, T. J., \& Sanna, L. J. (Eds), Social problem solving: Theory, research, and training (pp. 11-27.). Washington, DC: American Psychological Association.

Eagly, A. H., \& Chaiken, S. (1993). The psychology of attitudes. Orlando, FL: Harcourt Brace Jovanovich College. 
Eagly, A. H., \& Chaiken, S. (1995). Attitude strength, attitude structure, and resistance to change. In Petty, R. E., \& Krosnick, J. A. (Eds), Attitude strength: Antecedents and consequences (pp. 413-432.). NY: Psychology Press.

Endler, N. S., \& Parker, J. D. A. (1990a). Coping Inventory for Stressful Situations (CISS): Manual. Toronto: Multi-Health Systems.

Endler, N. S., \& Parker, J. D. A. (1990b). Multidimensional assessment of coping: A critical evaluation. Journal of Personality and Social Psychology, 58(5), 844-854. doi: 10.1037/0022-3514 .58 .5 .844

Endler, N. S., \& Parker, J. D. A. (1990c). State and trait anxiety, depression and coping styles. Australian Journal of Psychology, 42(2), 207-220. doi: 10.1080/00049539008260119

Endler, N. S., \& Parker, J. D. A. (1994). Assessment of multidimensional coping: Task, emotion, and avoidance strategies. Psychological Assessment, 6(1), 50-60. doi: 10.1037/1040-3590 .6 .1 .50

Endler, N. S., Speer, R. L., Johnson, J. M., \& Flett, G. L. (2000). Controllability, coping, efficacy, and distress. European Journal of Personality, 14(3), 245-264. doi: 10.1002/1099-0984$(200005 / 06) 14: 3<245:: A I D-P E R 375>3.0 . C O ; 2-G$

Endler, N. S., Summerfeldt, L. J., \& Kantor, L. (1993). Coping and controllability: an experimental manipulation. Nem publikált kézirat. York University, Canadian Psychological Association, 54th Annual Convention, Montreal, Quebec.

Folkman, S., \& Lazarus, R. S. (1980). An analysis of coping in a middle-aged community sample. Journal of Health and Social Behavior, 21(3), 219-239. doi: 10.2307/2136617

Folkman, S., Lazarus, R. S., Pimley, S., \& Novacek, J. (1987). Age differences in stress and coping processes. Psychology and Aging, 2(2), 171-184. doi: 10.1037/0882-7974.2.2.171

Haugtvedt, C. P., \& Kasmer, J. A. (2008). Attitude change and persuasion. In Haugtvedt, C. P., Herr, P. M., \& Kardes, F. R. (Eds), Handbook of Consumer Psychology (pp. 419-435.). NY, London: Psychology Press.

Kasik, L. (2015). Személyközi problémák és megoldásuk. Budapest: Gondolat Kiadó.

Kasik, L., Nagy, Á., \& Fúzy, A. (2009). Szociálisprobléma-megoldás kérdôiv. Szeged: SZTE BTK Neveléstudományi Intézet.

Lazarus, R. S., \& Folkman, S. (1984). Stress, appraisal and coping. NY: Springer Publishing Company.

Maydeu-Olivares, A., \& D'Zurilla, T. J. (1996). A factor-analytic study of the Social ProblemSolving Inventory: An integration of theory and data. Cognitive Therapy and Research, 20(2), 115-133. doi: 10.1007/BF02228030

Miller, G. R. (1980). On being persuaded: Some basic distinctions. In Dillard, J. P., \& Pfau, M. (Eds), The persuasion handbook: Developments in theory and practice (pp. 3-16.). Thousand Oaks, CA: Sage.

Nagy, L., \& Balázs, K. (2018a). Félelemkeltô egészségkommunikáció és a megküzdési stílus. Psychiatria Hungarica, 33(2), 106-124.

Nagy, L., \& Balázs, K. (2018b). Politikamentes félelemkeltố társadalmi célú reklámok hatásának vizsgálata. Magyar Pszichológiai Szemle, 73(2), 133-158. doi: 10.1556/0016.2018.73.2.2

Nagy, L., \& Balázs, K. (megjelenés alatt). A megküzdési stílus és a kontrollhely hatása a félelemkeltố reklámüzenetekre adott válaszokra. JUVENILIA 2019.

Parker, J. D. A., \& Endler, N. S. (1992). Coping with coping assessment: A critical review. European Journal of Personality, 6(5), 321-344. doi: 10.1002/per.2410060502

Perczel Forintos D., Kiss Zs., \& Ajtay Gy. (Eds) (2005). Kérdôivek, becslôskálák a klinikai pszichológiában. Budapest: Országos Pszichiátriai és Neurológiai Intézet.

Petty, R. E., \& Cacioppo, J. T. (1986). The Elaboration Likelihood Model of Persuasion. Advances In Experimental Social Psychology, 19, 123-205. doi: 10.1016/s0065-2601(08)60214-2 
Perloff, R. M. (2003). The dynamics of persuasion. Mahwah, NJ: Lawrence Erlbaum Associates, Publishers.

Rafnsson, F. D., Smari, J., Windle, M., Mears, S. A., \& Endler, N. S. (2006). Factor structure and psychometric characteristics of the Iceland version of the Coping Inventory for Stressful Situations (CISS). Personality and Individual Differences, 40(6), 1247-1258. doi: 10.1016/j. paid.2005.11.011

Rippetoe, P. A., \& Rogers, R. W. (1987). Effects of components of protection-motivation theory on adaptive and maladaptive coping with a health threat. Journal of Personality and Social Psychology, 52(3), 596-604. doi: 10.1037//0022-3514.52.3.596

Sas, I. (2010). Reklám a jóert. Budapest: Kommunikációs Akadémia Kft.

Síklaki, I. (1994). A meggyốzés pszichológiája. Budapest: MTA Pszichológiai Intézete.

So, J., Kuang, K., \& Cho, H. (2016). Reexamining fear appeal models from Cognitive Appraisal Theory and Functional Emotion Theory perspectives. Communication, 83(1), 120-144. doi: $10.1080 / 03637751.2015 .1044257$

Tiringer, I. (2014). Megküzdés (Coping). In Kállai, J., Varga, J., Oláh, J. (Eds), Egészségpszichológia a gyakorlatban (pp. 177-197.). Budapest: Medicina Könyvkiadó.

Witte, K. (1992). Putting the fear back into fear appeals: The Extended Parallel Process Model. Communication Monographs, 59, 329-349. doi: 10.1080/03637759209376276

Zsolnai A., \& Kasik L. (2016). Coping strategies and social problem solving in adolescence. In A. Surian (szerk.) Open spacies for interactions and learning diversities (pp. 121-126). Rotterdam: SensePublishers. 


\title{
TYPICAL COPING STYLES AND HANDLING SOCIAL PROBLEMS
}

\author{
NAGY, LUCA-BALÁZS, KATALIN
}

Background and purpose: The purpose of this study is to measure the behavioral intentions toward social problem-solving in line with coping styles and social problem-solving abilities. Attitudes and behavioral intentions of the Theory of Planned Behavior (TPB, Ajzen, 1991), and the literature of coping and of social problem-solving give the basis of the research. The empirical antecedents are our studies.

Method: The target group of the study was adults' age group. Respondents filled out questionnaires online or paper-pencil forms and answered the items of SPSI-R (Social Problem-Solving Inventory-Revised, D'Zurilla, Nezu and Maydeu-Olivares, 2002, adapted by Kasik, Nagy and Füzy, 2009) that investigate social problem-solving and CISS-48 (Coping Inventory for Stressful Situations, Endler and Parker, 1994) that measures coping styles. After that, they indicated their intentions regarding the solution of climate change, protection of natural habitat, diabetes, healthy lifestyle, donation to indigent children and prevention of violence. The sample of the study consisted of 275 participants, consisting 109 men and 166 women. The mean age was 30 years. Most of the participants had finished secondary education or had a college degree.

Results: According to the results, three groups of participants can be identified based on their behavioral intentions, and these groups can be characterized by different mean age, variant patterns of coping styles and social problem-solving abilities.

Conclusion: Although there are other factors which can affect behavioral intentions toward social problemsolving, coping and social problem-solving abilities could influence them together with the variable of age.

Keywords: attitude, behavioral intention, social issues, coping, social problem-solving ability

A cikk a Creative Commons Attribution 4.0 International License (https://creativecommons. org/licenses/by/4.0) feltételei szerint publikált Open Access közlemény, melynek szellemében a cikk bármilyen médiumban szabadon felhasználható, megosztható és újraközölhetô, feltéve, hogy az eredeti szerzó és a közlés helye, illetve a CC License linkje és az esetlegesen végrehajtott módosítások feltüntetésre kerülnek. (SID_1) 